\title{
PENGARUH PENERAPAN MODEL PEMBELAJARAN INKUIRI TERBIMBING TERHADAP KEMAMPUAN KONEKSI MATEMATIS SISWA SMP NEGERI 10 KENDARI
}

\author{
Wa Muli $^{\text {I) }}$, Jafar Masuha ${ }^{2)}$, La Ndia $^{3)}$ \\ ${ }^{1)}$ Alumni Jurusan Pendidikan Matematika, ${ }^{2,3}$ Dosen Jurusan Pendidikan Matematika \\ FKIP Universitas Halu Oleo Email : mulinana50@ gmail.com; jafar665@gmail.com; \\ alndifiat@gmail.com
}

\begin{abstract}
Abstrak
Penelitian eksperimen Posttest Only Control Group Design dengan tujuan: (1) mendeskripsikan kemampuan koneksi matematis siswa kelas VIII SMP Negeri 10 Kendari yang diajar dengan Inkuiri Terbimbing; (2) Mengetahui apakah ada pengaruh penerapan model pembelajaran Inkuiri Terbimbing terhadap kemampuan koneksi matematis siswa. Populasi seluruh siswa dan Pengambilan sampel menggunakan teknik random sampling. Hasil penelitian secara deskriptif dan secara inferensial menunjukan bahwa: (1) Aktivitas belajar dengan model Pembelajaran Inkuiri Terbimbing kelas VIII SMP Negeri 10 Kendari terkategori baik sebesar 70,31 \%. (2) Deskripsi kemampuan koneksi matematis dengan model pembelajaran Inkuiri Terbimbing lebih baik dibandingkan dengan pembelajaran konvensional (3) Terdapat pengaruh positif penerapan model Pembelajaran Inkuiri Terbimbing terhadap kemampuan koneksi matematis siswa di kelas VIII SMP Negeri 10 Kendari.
\end{abstract}

Kata Kunci : model pembelajaran; inkuiri terbimbing, kemampuan koneksi matematis

\section{THE EFFECT OF IMPLEMENTING THE MULTIPLE INQUIRY LEARNING MODEL ON THE ABILITY OF STUDENT MATHEMATICAL CONNECTIONS STATE 10 KENDARI PRIVATE VOCATIONAL SCHOOL}

\begin{abstract}
Experimental research Posttest Only Control Group Design with the aim of: (1) describing the mathematical connection ability of class VIII students of SMP Negeri 10 Kendari taught with Guided Inquiry; (2) Knowing whether there is an effect of applying the Guided Inquiry learning model to students' mathematical connection skills. The population of all students and sample collection using random sampling techniques. Descriptive and inferential research results show that: (1) Learning activities with the Guided Inquiry Learning model class VIII SMP Negeri 10 Kendari are categorized as good at $70.31 \%$. (2) Description of the mathematical connection ability with the Guided Inquiry learning model is better than conventional learning (3) There is a positive influence on the implementation of the Guided Inquiry Learning model on students' mathematical connection skills in class VIII of SMP Negeri 10 Kendari.
\end{abstract}

Keywords: effect of guided' inquiry learning model, mathematical connection ability. 


\section{Pendahuluan}

Pendidikan dapat diperoleh secara non formal yaitu dalam kehidupan keluarga dan masyarakat maupun secara formal yaitu di sekolah. Pendidikan yang baik akan mengembangkan potensi peserta didik secara optimal sehingga menjadi sumber daya manusia berkualitas yang dapat bersaing dalam dunia kerja.

Dalam pelaksanaan pendidikan formal, matematika termasuk mata pelajaran wajib yang diajarkan di sekolah, baik Sekolah Dasar (SD), Sekolah Menengah Pertama (SMP), maupun Sekolah Menengah Atas (SMA) bahkan menjadi salah satu pelajaran yang masuk dalam Ujian Nasional (UN). Hal ini dikarenakan matematika merupakan ilmu yang penting dan menjadi ilmu dasar untuk mempe lajari disiplin ilmu lain serta menyelesaikan masalah dalam kehidupan sehari-hari (Daryanto, 2013: 411).

Menurut Ruseffendi (2006: 71), dalam pelaksanaan pembelajaran matematika di suatu lembaga pendidikan itu sendiri bertujuan untuk meluruskan dan mempermudah siswa belajar berhitung dan cabang-cabang matematika lainnya. Hermawan (2007: 27) menyatakan fungsi dari pembelajaran matematika yaitu untuk mengembangkan kemampuan berkomunikasi dengan menggunakan bilangan dan simbol-simbol serta ketajaman penalaran yang dapat membantu memperjelas dan menyelesaikan permasalahan dalam kehidupan sehari-hari. Gagne dan Bring (2007) mengemukakan bahwa pembelajaran bukanlah sesuatu yang terjadi secara kebetulan, melainkan dengan adanya kemampuan guru yang dimiliki tentang dasar-dasar mengajar yang baik.

Hasil diskusi dengan salah seorang guru matematika SMP Negeri 10 Kendari, diperoleh informasi bahwa kemungkinan penyebab kelemahan siswa antara lain: (1) proses pembelajaran masih berpusat pada guru, (2) pola pengajaran selama ini masih dengan tahapan memberikan informasi tentang materi-materi matematika, memberikan contoh-contoh dan berikutnya latihan-latihan sehingga pengetahuan siswa bukan hasil konstruksi pemikiran sendiri, dan (3) dalam merencanakan menyelesaikan soal tidak diajarkan strategi-strategi yang bervariasi untuk menemukan jawaban soal. Proses pembelajaran biasanya dimulai dengan penjelasan konsep yang disertai contoh, di lanjutkan dengan mengerjakan latihan soal matematika, sehingga kemampuan penalaran siswa kurang berkembang, karena guru lebih membahas masalah yang sifatnya rutin atau masalahmasalah tertutup yang hanya memiliki satu jawaban yang benar dengan satu cara pemecahannya.

Namun pada kenyataannya menurut Rusgianto (Nurhadiyani: 2011) menyatakan bahwa kemampuan siswa mengaplikasikan pengetahuan matematika yang dimilikinya dalam kehidupan nyata masih belum memuaskan. Berdasarkan keterangan yang peneliti peroleh dari salah seorang guru di SMPN 10 Kendari, bahwa hasil belajar siswa kelas VIII khususnya kelas VIII-1 dan VIII-6 masih banyak yang di bawah KKM. Hal ini bisa dilihat dalam mengerjakan latihan maupun ulangan, siswa kurang mampu dalam menerjemahkan kalimat matematika kedalam model matematika atau sebaliknya. Siswa juga tidak mampu menjelaskan materi yang diberikan dalam konteks kehidupan sehari-hari maupun yang bersifat abstrak. Kemudian siswa cenderung tidak dapat menjawab soal yang tidak sesuai dengan contoh yang diberikan oleh guru dalam pembelajaran, sehingga siswa hanya menebak-nebak jawaban tanpa memperhatikan proses penyelesaiannya. Indikator-indikator tersebut yang menunjukkan kemampuan koneksi yang rendah. Begitupun menurut Setiawan (Sopandi, 2010: 2) kenyataan di lapangan menunjukkan bahwa kemampuan siswa dalam melakukan koneksi matematika masih tergolong rendah. Menurut National Council of Teacher of Mathematics (NCTM) dalam Yulianti (2005), koneksi matematika merupakan bagian penting yang harus 
mendapatkan penekanan di setiap jenjang pendidikan.

Penyebab nilai matematika peserta didik rendah karena kurangnya kemampuan peserta didik dalam menghubungkan materi yang dipelajari dengan materi sebelumnya. Serta kurangnya peserta didik berlatih soalsoal yang mengasah kemampuan berpikir, sehingga hanya sedikit peserta didik yang dapat menyelesaikan soal terkait kehidupan sehari-hari yang telah diajarkan oleh guru dan banyak peserta didik yang belum dapat menyelesaikan soal yang diberikan guru karena peserta didik bingung dalam memahami materi yang ditanyakan dalam soal terkait dalam kehidupan sehari-hari.

Memperlihatkan akar masalah itu, dilihat dari rendahnya kemampuan koneksi matematis siswa maka perlu dipikirkan caracara mengatasinya. Oleh sebab itu, diperlukan suatu upaya untuk menyelesaikan masalah tersebut, yaitu menerapkan suatu model pembelajaran yang dirancang dan dilaksanakan dengan baik sehingga dapat membantu berkembangnya kemampuan koneksi matematis siswa. Salah satu model pembelajaran yang bisa diterapkan adalah model Pembelajaran Inkuiri Terbimbing.

$$
\text { Model pembelajaran inkuiri }
$$
terbimbing adalah model penemuan yang dirancang untuk menyesuaikan kemampuan dan tingkat perkembangan intelektual peserta didik, mengurangi ketergantungan kepada guru dan memberi pengalaman seumur hidup melalui proses mental mengasimilasikan konsep dan prinsip. Model pembelajaran Inkuiri Terbimbing melibatkan proses penelitian yang didorong oleh pertanyaan demi pertanyaan dan membuat penemuan dalam usaha mencari pemahaman atau jawaban yang baru. Dalam proses pembelajaran dengan metode Inkuiri Terbimbing, siswa dituntut untuk menemukan konsep melalui petunjukpetunjuk seperlunya dari seorang guru. Petunjuk-petunjuk itu pada umumnya berupa pertanyaan-pertanyaan yang bersifat membimbing (Wartono, 2009). Selain memberikan pertanyaan, guru juga dapat memberikan penjelasan-penjelasan seperlunya pada saat siswa akan melakukan percobaan, misalnya penjelasan tentang cara-cara melakukan percobaan. Model pembelajaran Inkuiri bertujuan untuk memberikan cara dan kebebasan siswa dalam membangun konsep dengan bahasa dan kemampuan koneksi matematis dalam diri mereka. Dalam penerapan model pembelajaran ini, Ibrahim dalam (Paidi, 2007: 8) menerangkan Guided ingkuiry sebagai kegiatan ingkuiri di mana siswa diberikan kesempatan untuk bekerja merumuskan prosedur, menganalisis hasil, dan mengambil kesimpulan secara manddiri, sedangkan dalam hal menentukan topik, pertanyaan dan bahan penunjang, guru hanya sebagai fasilitator. Pada dasarnya model pembelajaran Ingkuiri Terbimbing lebih menekankan kepada proses mencari dan menemukan, dimana materi pelajaran tidak diberikan secara langsung kepada peserta didik.

Sanjaya (2008: 196) bahwa ada beberapa hal yang menjadi ciri utama strategi pembelajaran inkuiri diantaranya sebagai berikut. 1) strategi inkuiri menekankan kepada aktifitas siswa secara maksimal untuk mencari dan menemukan, artinya siswa ditempatkan sebagai subjek belajar. Dalam proses belajar siswa tidak hanya berperan sebagai penerima pelajaran melalui penjelasan guru secara verbal, tetapi mereka berperan untuk menemukan sendiri inti dari materi pelajaran itu sendiri. 2) seluruh aktifitas yang dilakukan siswa diarahkan untuk mencari dan menemukan sendiri dari sesuatu yang dipertanyakan, sehingga diharapkan dapat menumbuhkan sikap percaya diri. Artinya dalam pendekatan inkuiri menempatkan guru bukan hanya sebagai sumber belajar, akan tetapi sebagai fasilitator dan motivator belajar siswa. Aktivitas pembelajaran biasanya dilakukan melalui proses tanya jawab antara guru dan siswa, sehingga kemampuan guru dalam menggunakan teknik bertanya merupakan syarat utama dalam melakukan inkuiri. 3) tujuan dari 
penggunaan strategi pembelajaran inkuiri adalah mengemabangkan kemampuan intelektual sebagai bagian dari proses mental, akibatnya dalam pembelajaran inkuiri siswa tidak hanya dituntut agar menguasai pelajaran, akan tetapi bagaimana mereka dapat menggunakan potensi yang dimilikinya. Dengan begitu siswa akan dengan sendirinya mengasah serta melatih kemampuan koneksi matematis mereka. Artinya melalui pembelajaran ini siswa di harapkan untuk dapat mengomunikasikan tentang apa yang telah dipelajari lalu kemudian membangun suatu pengetahuan dengan konsep yang sudah dia dapatkan melalui proses pembelajaran.

Model pembelajaran Ingkuiri merupakan model pembelajaran yang banyak dianjurkan dan digunakan di sekolah khususnya sekolah dasar. Menurut Sanjaya (2009) ada beberapa keunggulan dari model pembelajaran ini diantaranya sebagai berikut.

a. Model pembelajaran Ingkuiri merupakan model pembelajaran yang menekankan kepada pengembangan aspek kognitif, afektif, dan psikomotor secara seimbang sehingga pembelajaran melalui model ini dianggap lebih bermakna

b. Model pembelajaran Ingkuiri dapat memberikan ruang kepada peserta didik untuk belajar sesuai dengan gaya belajar mereka.

c. Model pembelajaran Ingkuiri merupakan model pembelajaran yang dianggap sesuai dengan perkembangan psikologi modern yang menganggap belajar adalah proses perubahan tingkah laku berkat adanya pengalaman.

d. Dapat melayani kebutuhan peserta didik yang memiliki kemampuan diatas ratarata artinya peserta didik yang memiliki kemampaun belajar bagus tidak akan terhambat oleh peserta didik yang lemah dalam belajar.

Model pembelajaran Ingkuiri juga memiliki kelemahan. Sebagaimana dikemukakan oleh Sanjaya (2009) diantaranya sebagai berikut. a. Jika model pembelajaran Ingkuiri digunakan sebagai model pembelajaran, maka akan sulit mengontrol kegiatan dan keberhasilan peserta didik.

b. Model ini sulit dalam merencanakn pembelajaran oleh karena terbentur dengan kebiasaan peserta didik dalam belajar.

c. Kadang-kadang dalam mengimplementasikannya memerlukan waktu yang panjang sehingga guru sulit menyesuaikan waktu.

d. Selama kriteria keberhasilan belajar ditentukan oleh kemampuan peerta didik menguasai materi pelajaran, maka model pembelajaran Ingkuiri akan sulit diimplementasikan oleh setiap guru.

Dengan demikian, dalam penelitian ini model pembelajaran Ingkuiri Terbimbing merupakan proses investigasi yang bertujuan untuk meningkatkan kemampuan peserta didik dalam merumuskan prosedur, menganalisis hasil, dan mengambil kesimpulan secara mandiri dan guru sebagai fasilitator.

Koneksi matematis merupakan dua kata yang berasal dari Mathematical Connection, yang dipopulerkan oleh NCTM dan dijadikan sebagai standar kurikulum pembelajaran matematika sekolah dan menengah (Sumarno, 2006). Untuk dapat melakukan koneksi terlebih dahulu mengerti dengan permasalahannya dan untuk dapat mengerti permasalahan harus mampu membuat koneksi dengan topik-topik yang terkait. Bruner (Suherman, 2001: 45) menyatakan bahwa tidak ada konsep atau operasi dalam matematika yang tidak terkoneksi dengan konsep atau operasi lain dalam suatu sistem, karena suatu kenyataan bahwa esensi matematika merupakan sesuatu yang selalu terkait dengan sesuatu yang lain. Membuat koneksi merupakan cara untuk menciptakan pemahaman dan sebaliknya memahami sesuatu berarti membuat koneksi. Persepsi bahwa konsepkonsep matematika merupakan konsepkonsep yang saling berkaitan dalam pembelajaran matematika di sekolah. Jika 
persepsi ini sebagai landasan guru dalam pembelajaran matematika maka setiap mengkaji materi selalu mengaitkan dengan materi lain dalam kehidupan sehari-hari.

$$
\text { Koneksi matematis adalah }
$$
pengaitan matematika dengan pelajaran lain atau topik lain. Menurut NCTM (1989), ada dua tipe umum koneksi matematis, yaitu modeling connection dan mathematical connection. Modeling connection merupakan hubunngan antara situasi masalah yang muncul di dunia nyata atau dalam disiplin ilmu lain dengan representasi matematisnya, sedangkan mathematical connection adalah hubungan antara dua representasi yang ekuivalen, dan antara proses penyelesaian dari masing-masing reprsentasi.

Koneksi dalam matematika merupakan hubungan dari ide-ide atau gagasan yang digunakan untuk merumuskan dan menguji topik-topik matematika secara deduktif.Konsep dan prosedur matematika di kembangkan untuk menyelesaikan matematika dan juga ilmu selain matematika. Indikator untuk kemampuan koneksi matematika siswa menurut Sumarmo (2006) sebagai berikut. 1)Mencari dan memahami hubungan berbagai representasi konsep dan prosedur. 2)Menggunakan matematika dalam bidang studi lain atau kehidupan sehari-hari. 3)Memahami representasi ekuivalen konsep atau prosedur yang sama. 4) Mencari koneksi satu dengan prosedur ke prosedur lain dalam reprsentasi yang ekuivalen. 5) Menggunakan koneksi antar topik matematika, dan antara topik matematika dengan topik lain. Berdasarkan hasil survey NCTM (National Council of Teacher of Mathematics) (2000: 64), indikator untuk kemampuan koneksi matematis yaitu. 1) Mengenali dan memanfaatkan hubunganhubungan antara gagasan dalam matematika, 2) memahami bagaimana gagasan dalam matematika saling berhungan dan mendasari satu sama lain, dan 3) menerapkan matematika dalam konteks-konteks di luar matematika. Ulep (Widarti, 2013: 2) menguraikan indikator koneksi matematis sebagai berikut. 1) menyelesaikan masalah dengan menggunakan grafik, hitungan numerik, aljabar, dan representasi verbal, 2) menerapkan konsep dan prosedur yang telah diperoleh pada situasi baru, 3) menyadari hubungan antar topik dalam matematika, dan 4) memperluas ide-ide matematis.

Berdasarkan beberapa teori diatas, dapat disimpulkan bahwa kemampuan koneksi matematis adalah kemampuan siswa dalam mencari hubungan suatu representasi konsep dan prosedur, memahami antar topik matematika, dan kemampaun siswa dalam mengaplikasikan konsep matematika dalam bidang lain atau dalam kehidupan seharihari. Penelitian yang sejalan dengan penelitian ini adalah Penelitian yang dilakukan oleh Novrian (2016) kemampuan komunikasi matematis siswa yang mengikuti pembelajaran dengan model pembelajaran Ingkuiri Terbimbing lebih tinggi daripada siswa yang mengikuti pembelajaran konvensional ditinjau dari keefektifan penerapan pembelajaran.

Hal yang sama juga diperoleh dari penelitian penelitian yang sebelumnya dilakukan oleh Sonni (2014) pada kelas VIII SMP Negeri 10 Prambanan Sleman, dalam penelitiannya menyimpulkan bahwa Ingkuiri Terbimbing dapat meningkatkan kemampuan komunikasi matematis siswa.

Menurut penelitian yang dilaksanakan oleh Arif (2013) yang mengkaji tentang Kemampuan Konekasi Matematis dalam Menyelesaikan masalah kontekstual ditinjau dari siswa yang berkemampuan matematis tinggi mempunyai koneksi sangat baik dengan memenuhi empat indikator koneksi matematis, siswa yang berkemampuan matematis sedang memenuhi tiga indikator koneksi matematis dengan baik dan siswa yang berkemampuan matematis rendah memenuhi dua indikator koneksi matematis yang baik.

\section{Metode}

Jenis penelitian ini adalah penelitian eksperimen posttest only control group design yaitu penelitian yang menggunakan 
posttest pada pertemuan terakhir untuk membandingkan suatu kelompok (eksperimen) yang diberi perlakuan khusus dengan satu kelompok (kontrol) pembanding yang tidak menerima perlakuan khusus.

Populasi dalam penelitian ini adalah siswa kelas VIII SMP Negeri 10 Kendari yang tersebar dalam delapan kelas paralel yaitu $\mathrm{VIII}_{1}$ - $\mathrm{VIII}_{8}$ yang berjumlah 229 orang siswa yang tersebar dalam 8 kelas paralel. Sampel dalam penelitian ini dipilih dengan menggunakan teknik purposive sampling. Sampel yang dibutuhkan dalam penelitian adalah sebanyak dua kelas, dengan menggunakan teknik purposive sampling dimana pemilihan sampelnya secara sengaja dipilih dari banyak kelas untuk mengambil dua kelas yang berkemampuan relatif sama.Teknik sampling ini dipilih berdasarkan kemampuan yang relatif sama yang dilihat dari rata-rata dan varians nilai ulangan akhir semester matematika pada semester genap kelas VIII tahun ajaran 2018. Adapun penentuan kelas yang digunakan sebagai kelas eksperimen dan kelas kontrol dilakukan secara acak (class random sampling) dimana diperoleh kelas $\mathrm{VIII}_{1}$ sebagai kelas kontrol dan $\mathrm{VIII}_{6}$ sebagai kelas eksperimen.

Variabel yang digunakan dalam penelitian ini terdiri dari variabel bebas (independen) pada penelitian ini yaitu pendekatan model pembelajaran Inkuiri Terbimbing (X) dan variabel terikat (dependen) pada penelitian ini yaitu kemampuan koneksi matematis siswa yang diajar dengan menggunakan penerapan model pembelajaran Ingkuiri Terbimbing (Y). Untuk memudahkan memahami variabel dalam penelitian ini, maka variabelvariabel tersebut perlu di defenisikan secara operasional.Defenisi orerasional dari variabel-variabel tersebut adalah sebagai berikut.

a. Model pemebelajaran Ingkuiri terbimbing (Guied Ingkuiri learning) merupakan model pembelajaran yang menciptakan situasi belajar yang melibatkan peserta didik belajar secara aktif dan mandiri dalam menemukan suatu konsep atau teori, pemahaman, dan pemecahan masalah. Proses penemuan tersebut membutuhkan guru sebagai fasilitator dan pembimbing. Banyaknya bantuan yang diberikan guru tidak mempengaruhi peserta didik untuk melakukan penemuan sendiri. Dalam model ini, peserta didik didorong untuk berpikir sendiri, menganalisis sendiri, sehingga dapat menemukan prinsipprinsip umum berdasarkan bahan-bahan atau data yang telah disediakan oleh guru. Seberapa jauh bantuan yang diberikan tergantung kemampuan ratarata peserta didik dan karakteristik materi yang dipelajari.

b. Kemampuan koneksi matematis merupakan kemampuan siswa untuk mengaitkan antar unit dalam matematika, mengaitkan konsep matematika dengan kehidupan seharihari dan mengaitkan konsep matematika dengan disiplin ilmu lain.kemampuan koneksi matematis siswa dapat diukur dengan menggunakan indikator kemampuan koneksi matematis sebagai berikut: (1) menemukan hubungan dari berabagai represenatasi tentang konsep dan prosedur matematika. (2) memahami antar topik dalam matematika. (3) mampu menggunakan matematika dalam penyelesaian masalah dalam kehidupan sehari-hari. (4) memahami representasi konsep yang ekuivalen. (5) menemukan hubungan antara prosedur satu dengan yang lainnya. (6) menggunakan koneksi antara matematika dengan matematika sendiri maupun dengan ilmu lain.

Desain penelitian yang digunakan adalah posttest only control design yaitu penelitian melibatkan dua kelas sampel (kelas eksperimen dan kelas kontrol) yang masing-masing dipilih secara random (R) dimana kelas eksperimen diberi perlakuan (X) dan kelas kontrol tidak diberi perlakuan. Desain penelitian disajikan dalam Tabel berikut. 
Tabel 1

Desain Eksperimen

\begin{tabular}{|c|c|c|c|}
\hline & Kelas & Perlakuan & Posttest \\
\hline $\mathrm{R}$ & $\mathrm{E}$ & $\mathrm{X}$ & $\mathrm{O}_{1}$ \\
\hline $\mathrm{R}$ & $\mathrm{K}$ & - & $\mathrm{O}_{2}$ \\
\hline
\end{tabular}

Keterangan:

$\mathrm{E}=$ Eksperimen

$\mathrm{K}=$ Kontrol

$\mathrm{X}=$ Perlakuan berupa penerapan model pembelajaran Inkuiri Terbimbing pada kelas eksperimen

$\mathrm{O}_{1}=$ Hasil posttest siswa pada kelas eksperimen

$\mathrm{O}_{2}=$ Hasil posttest siswa pada kelas kontrol

Instrumen penelitian Pada penelitian ini mempunyai instrument berupa tes kemampuan koneksi matematis siswa. Instrumen yang digunakan untuk mengukur kemampuan koneksi matematis siswa pada pokok bahasan relasi dan fungsi adalah tes uraian sebanyak 6 soal bentuk uraian untuk mengukur kemampuan koneksi matematis siswa. Penggunaan soal bentuk uraian dikarenakan soal bentuk uraian dapat digunakan untuk mengukur kegiatankegiatan belajar yang sulit diukur oleh soal dalam bentuk objektif. Peneliti menggunakan bentuk uraian dengan tujuan agar siswa dapat menguraikan dan menyatakan jawaban dengan kata-kata sendiri dalam bentuk, teknik dan gaya yang berbeda satu dengan yang lainnya.

Sebelum instrumen penelitian digunakan terlebih dahulu akan diuji cobakan untuk mengetahui apakah tes tersebut telah memenuhi syarat tes yang baik dengan menguji validitas dan realibilitas. Uji validitas penelitian yang dilakukan pada penelitian ini adalah uji coba instrument. Untuk tes uraian, validitas butir tesnya dihitung dengan menggunakan rumus korelasi product moment dengan angka kasar sebagai berikut.

$\mathrm{r}_{X Y}=\frac{N \sum X Y-\left(\sum X\right)\left(\sum Y\right)}{\sqrt{\left\{N \sum X^{2}-\left(N \sum X\right)^{2}\right\}\left\{N \sum Y^{2}-\left(N \sum Y\right)^{2}\right.}}$
(Sundayana, 2016: 59-60).

Keterangan :

$\mathrm{r}_{\mathrm{XY}}=$ Koefisien korelasi antara variabel $\mathrm{X}$ dan variabel $\mathrm{Y}$

$\sum X Y=$ Jumlah perkalian antara skor X dan skor $\mathrm{Y}$

$\mathrm{N}$ = Jumlah responden

$\mathrm{X}=$ Skor item butir soal

$\mathrm{Y}=$ Jumlah skor total tiap soal

Sedangkan untuk mengetahui koefisien reliabilitas tes kemampuan koneksi matematis siswa adalah dengan menggunakan rumus Alpha Cronbach yaitu sebagai berikut

$\mathbf{r}_{11}=\left[\frac{n}{n-1}\right]\left[1-\frac{s_{i}{ }^{2}}{s_{t}{ }^{2}}\right]$

$\mathrm{n}=$ banyaknya butir soal

$s_{i}^{2}=$ banyaknya butir soal yang valid

$s_{t}^{2}=$ varians skor total

Selanjutnya dalam pemberian interpretasi terhadap koefisien reliabilitas tes $\left(r_{11}\right)$ pada umumnya digunakan patokan :

$$
\begin{aligned}
& \mathrm{r}_{11} \leq 0,20 \\
& \text { reliabilitas : sangat rendah } \\
& 0,20<\mathrm{r}_{11} \leq 0,40 \\
& \text { reliabilitas : rendah } \\
& 0,40<\mathrm{r}_{11} \leq 0,60 \\
& \text { reliabilitas : sedang } \\
& 0,60<\mathrm{r}_{11} \leq 0,80 \\
& \text { reliabilitas : tinggi } \\
& 0,80<\mathrm{r}_{11} \leq 1,00 \\
& \text { reliabilitas : sangat tinggi }
\end{aligned}
$$

(Ruseffendi dalam Jihad dan Haris, 2012: 181). 
Instrumen butir soal dengan koefisien realibilitas dengan kategori sangat rendah dan rendah tergolong tidak reliabel. Instrumen butir soal yang tergolong reliabel adalah instrumen dengan koefisien reliabilitas kategori sedang, tinggi, dan sangat tinggi. Berdasarkan koefisien reliabilitasnya sebesar 0,685 diinterpretasikan dalam kategori tinggi. Sehingga dapat disimpulkan bahwa instrumen tes pada penelitian ini adalah valid dan reliabel, sehingga instrumen tersebut layak digunakan untuk mengukur kemampuan koneksi matematis siswa SMP Negeri 10 Kendari kelas VIII pada materi relasi dan fungsi.

Teknik pengumpulan data yang digunakan dalam penelitian ini adalah dengan memberikan tes kemampuan koneksi matematis berupa tes uraian yang diberikan kepada siswa kelas yang diteliti. Untuk memperoleh data dalam penelitian ini dilaksanakan tes hasil kemampuan koneksi matematis siswa. Setelah kegiatan pembelajaran menggunakan model pembelajaran inkuiri terbimbing maka diadakan posttest untuk mengetahui hasil kemampuan koneksi matematis siswa. Dari tes tersebut dilakukan penskoran terhadap jawaban siswa untuk tiap butir soal. Selanjutnya, hasil pekerjaan siswa dikumpulkan oleh peneliti untuk diperiksa dan dikoreksi serta diberi nilai. Nilai dari hasil pekerjaan siswa tersebut kemudian dijadikan data dalam penelitian ini.

Analisis data dalam penelitian ini menggunakan analisis deskriptif dan analisis inferensial. Analisis deskriptif dimaksudkan untuk mendeskripsikan kemampuan koneksi matematis siswa.Analisis deskriptif merupakan analisis yang digunakan untuk menggambarkan keadaan sampel dalam bentuk persentase $(\%)$, rata-rata $(\mathrm{x})$, median (Me), modus (Mo), standar deviasi (s), varians $\left(\mathrm{s}^{2}\right)$, nilai maksimum $\left(\mathrm{X}_{\text {maks }}\right)$, nilai minimum $\left(\mathrm{X}_{\mathrm{min}}\right)$, kurtosis dan Skewness.dan Analisis inferensial dilakukan untuk menguji hipotesis penelitian. Sebelum dilakukan pengujian hipotesis terlebih dahulu dilakukan uji normalitas dan uji homoenitas sebagai uji prasyarat untuk pengujian hipotesis penelitian dengan menggunakan uji-t. Uji normalitas merupakan uji statistik yang digunakan untuk mengetahui apakah data kelas yang diteliti berdistribusi normal atau tidak. Uji normalitas pada kelas eksperimen dan kelas kontrol menggunakan uji Kolmogorov-Smirnov dilakukan dengan menggunakan program SPSS. Uji homogenitas merupakan uji parametris yang menguji perbedaan antara kedua kelompok atau beberapa kelompok yang berbeda subjeknya atau sumber datanyauntuk mengetahui apakah kedua kelompok memiliki varians yang sama atau tidak. Apabila kedua kelompok mempunyai varians yang sama maka pengujian hipotesisnya dilakukan dengan uji-F dengan rumus menurut Sundayana (2015: 144) sebagi berikut.

$$
\mathrm{F}_{\text {hitung }}=\frac{\text { varians terbesar }}{\text { varians terkecil }}
$$

Data dalam penelitian ini setelah dilakukan uji normalitas dan uji homogenitas diperoleh bahwa data terdistribusi normal dan varians homogen selanjutnya melakukan uji hipotesis dengan menggunakan rumus uji-t. Rumus t-test sebagai berikut (Sundayana, 2015: 146).

$$
\mathrm{t}_{\text {hitung }}=\frac{\bar{X}_{1}-\bar{X}_{2}}{\mathrm{~s}_{\mathrm{g}} \sqrt{\frac{1}{n_{1}}+\frac{1}{n_{2}}}}
$$

dengan:

$$
S_{g}=\sqrt{\frac{\left(n_{1}-1\right) S_{1}^{2}+\left(n_{2}-1\right) S_{2}^{2}}{n_{1}+n_{2}-2}}
$$

Keterangan:

$\mathrm{t}_{\text {hitung }}=$ Nilai hitung untuk uji-t

$\bar{X}_{1}=$ Rata-rata skor responden kelas eksperimen

$\bar{X}_{2}=$ Rata-rata skor responden kelas kontrol

$\mathrm{n}_{1}=$ Jumlah responden kelas eksperimen

$\mathrm{n}_{2}=$ Jumlah responden kelas kontrol

$\mathrm{S}_{\mathrm{g}}=$ Simpangan baku gabungan 
$\mathrm{S}_{1}^{2}=$ Varians data sampel kelas eksperimen

$\mathrm{S}_{2}^{2}=$ Varians data sampel kelas kontrol

\section{Hasil}

Analisis data tes kemampuan koneksi matematis siswa kelas VIII $_{1}$ SMP Negeri 10 Kendari yang diajar dengan menggunakan model pembelajaran Ingkuiri Terbimbing dan kelas VIII $_{6}$ SMP Negeri 10 Kendari yang diajar dengan menggunakan model pembelajaran konvensional dapat dilihat pada hasil penelitian dengan menggunakan

Tabel 2

Deskriptif Kemampuan Koneksi Matematis Siswa

Kelas Eksperimen dan kelas Kontrol

\begin{tabular}{|c|c|c|}
\hline Statistik Deskriptif & Kelas Eksperimen & Kelas Kontrol \\
\hline Rata-rata & 78,35 & 72,14 \\
\hline $\mathrm{N}$ & 29 & 29 \\
\hline Standar deviasi & 5,07 & 5,40 \\
\hline Varians Sampel & 25,73 & 29,12 \\
\hline Nilai Maksimum & 92,00 & 84,00 \\
\hline Nilai Minimum & 72,00 & 60,00 \\
\hline Modus & 80,00 & 72,00 \\
\hline Median & 80,00 & 72,00 \\
\hline Skewness & 0,526 & 0,214 \\
\hline
\end{tabular}

Berdasarkan hasil analisis deskriptif dari data yang diperoleh melalui tes kemampuan koneksi matematis siswa, pada posttest kelas eksperimen diperoleh nilai rata-rata yang lebih tinggi dari pada nilai rata-rata yang diperoleh pada posttest kelas kontrol. Berdasarkan nilai rata-rata, maka kemampuan koneksi matematis siswa kelas eksperimen lebih tinggi dari kemampuan koneksi matematis siswa kelas kontrol. Hal ini mengindikasikan bahwa dari indikator rata-rata, model pembelajaran ingkuiri terbimbing mampu memberikan pengaruh yang cukup baik dalam meningkatkan kemampuan koneksi matematis siswa. Dari dua analisis yaitu hasil analisis deskriptif dan hasil analisis inferensial dengan menggunakan bantuan aplikasi SPSS.

Hasil analisis deskriptif kemampuan koneksi matematis siswa dari data posttest pada kelas eksperimen yang berjumlah 29 siswa dan kelas kontrol yang berjumlah 29 siswa. Diperoleh data posttest kemampuan koneksi matematis siswa kelas eksperimen dan kelas kontrol disajikan pada Tabel 2 berikut.

indikator keragaman data (varians), data posttest kelas eksperimen memiliki varians lebih kecil dibandingkan varians data posttest kelas kontrol. Nilai varians dari kedua data tersebut menunjukkan bahwa kemampuan koneksi matematis siswa kelas kontrol lebih beragam daripada kelas eksperimen. Dari indikator Skewness (kemiringan), kelas eksperimen memiliki lebih banyak siswa yang kemampuan koneksi matematis siswa di atas rata-rata, sedangkan pada kelas kontrol memiliki lebih banyak siswa yang kemampuan koneksi matematiss di bawah rata-rata. Median (nilai tengah) dan nilai yang sering muncul 
(modus) dari hasil posttest kelas eksperimen lebih tinggi dibandingkan dengan hasil pada posttest kelas kontrol.

Tahap selanjutnya dalam analisis data adalah analisis inferensial. Melalui analisis inferensial kita dapat mengetahui apakah hipotesis dalam penelitian ini diterima atau ditolak. Dalam analisis inferensial, terdapat beberapa tahap analisis yang menjadi prasyarat untuk melakukan analisis uji hipotesis yaitu analisis uji normalitas data dan analisis uji homogenitas data. Uji normalitas data dimaksudkan untuk mengetahui apakah data berasal dari populasi yang berdistribusi normal atau tidak, sedangkan uji homogenitas dimaksudkan untuk mengetahui apakah data yang diperoleh homogen terhadap populasinya atau tidak, setelah melalui syarat uji normalitas dan homogenitas maka dilanjutkan dengan uji hipotesis.

Uji normalitas digunakan untuk mengetahui apakah data kemampuan koneksi matematis siswa kedua kelas berdistribusi normal atau tidak. Untuk menguji apakah data berdistribusi normal atau tidak digunakan statistik uji normalitas dengan rumus Kolmogorov-Smirnov, menggunakan program SPSS. Hasil perhitungannya disajikan dalam Tabel 4.2 berikut.

Tabel 3

Hasil Analisis Statistik Uji Normalitas DataPosttes

Kemampuan Koneksi Matematis Siswa pada

Kelas Kontrol dan Kelas Eksperimen

One-Sample Kolmogorov-Smirnov Test

\begin{tabular}{|c|c|c|c|}
\hline & & $X$ & $\mathrm{Y}$ \\
\hline \multicolumn{2}{|l|}{$\mathrm{N}$} & 29 & 29 \\
\hline \multirow{2}{*}{$\begin{array}{l}\text { Normal } \\
\text { Parameters }^{\mathrm{a}}\end{array}$} & Mean & 17,17 & $\begin{array}{r}20.3 \\
3\end{array}$ \\
\hline & $\begin{array}{l}\text { Std. } \\
\text { Deviation }\end{array}$ & 3,088 & $\begin{array}{r}3,44 \\
7\end{array}$ \\
\hline \multirow{3}{*}{$\begin{array}{l}\text { Most } \\
\text { Extreme } \\
\text { Differences }\end{array}$} & Absolut & 0,103 & $\begin{array}{r}0,10 \\
2\end{array}$ \\
\hline & Positive & 0,078 & 0,08 \\
\hline & Negativ & $-0,103$ & $0,102^{-}$ \\
\hline \multicolumn{2}{|c|}{ Kolmogorov-Smirnov Z } & 0,507 & $\begin{array}{r}0,50 \\
1\end{array}$ \\
\hline \multicolumn{2}{|c|}{ Asymp. Sig. (2-tailed) } & 0,959 & $\begin{array}{r}0,96 \\
3\end{array}$ \\
\hline
\end{tabular}

Pada Tabel 4.2 di atas dapat dilihat bahwa nilai Asymp. Sig. (2-tailed) untuk kelas eksperimen adalah 0,963> $\alpha$ (dengan $\alpha=0,05)$, sehingga $\mathrm{H}_{0}$ diterima. Hal ini berarti bahwa data kemampuan koneksi matematis siswa pada kelas eksperimen berdistribusi normal.Sedangkan untuk kelas kontrol terlihat bahwa nilai Asymp. Sig. (2- tailed) adalah $0,959>\alpha$ (dengan $\alpha=0,05$ ), sehingga $\mathrm{H}_{0}$ diterima. Hal ini berarti bahwa data kemampuan koneksi matematis siswa pada kelas kontrol juga berdistribusi normal. Uji homogenitas digunakan untuk mengetahui apakah data mempunyai varians yang sama (homogen) atau tidak. Untuk menguji apakah data mempunyai varians 
yang sama atau tidak digunakan statistik uji Levene dengan menggunakan program SPSS

seperti yang disajikan pada Tabel 4.3berikut.

Tabel 4

Hasil Analisis Statistik Uji HomogenitasPost Tes Kemampuan Koneksi Matematis Siswa Kelas Eksperimen dan

Kelas Kontrol

Test of Homogeneity of Variances

kemampuan_koneksi

\begin{tabular}{|l|l|l|l|}
\hline $\begin{array}{c}\text { Levene } \\
\text { Statistic }\end{array}$ & df1 & df2 & Sig. \\
\hline & 1 & 56 & 0.632 \\
\hline
\end{tabular}

Dari tabel 4.3 di atas terlihat bahwa nilai signifikan statistik uji Levene adalah 0,232 . Nilai signifikan ini lebih besar dari taraf signifikan 0,05 ( nilai sig. $(0,632$ ) $>\alpha$ dengan $\alpha$ 0,05), maka $\mathrm{H}_{0}$ diterima. Sehingga dapat disimpulkan bahwa kedua kelompok memiliki varians yang sama. Ini berarti data post tes kedua kelompok yaitu yang mendapat model pembelajaran ingkuiri terbimbing dan model pembelajaran konvensional memiliki varians yang sama (homogen). Pengujian hipotesis menggunakan uji-t data sampel saling bebas (Independent Sample t-test) dilakukan dengan rumus uji-t menggunakanSPSS.

Berdasarkan hasil analisis uji-t diperoleh $\mathrm{t}_{\text {hitung }}=4,513>\mathrm{t}_{\text {tabel }}=1,703$ atau nilaisig. $(2-$ tailed $)=0,000<0.05$, maka $\mathrm{H}_{0}$ ditolak. Dengan ditolaknya $\mathrm{H}_{0}$, maka dapat disimpulkan bahwa terdapat pengaruh positif yang signifikan penggunaan model pembelajaran Ingkuiri terbimbing terhadap kemampuan koneksi matematis siswa.

\section{Pembahasan}

Salah satu penyebab sulitnya mengembangkan kemampuan koneksi matematis dalam mata pelajaran matematika adalah guru belum melakukan pendekatan pembelajaran yang tepat untuk meningkatkan kemampuan koneksi matematis siswa. Guru pada umumnya tidak menyajikan latihan kepada siswa yang mengarah pada pengembangan kemampuan koneksi matematis karenasetiap latihan yang diberikan hanya berorientasi pada hasil tanpa melihat bagaimana proses yang dijalankan oleh siswa, sedangkan siswa sendiri tidak terbiasa dengan latihan atau soal-soal dengan tahap penyelesaian yang utuh mulai dari tahap memahami masalah, menyelesaikan masalah dan menjawab masalah, biasanya siswa hanya menuliskan rumus dan melakukan penyelesaian. Oleh karena itu, guru perlu menyusun suatu model pembelajaran yang dapat memperbaiki pembelajaran dan mampu mengembangkan kemampuan pemecahan masalah matematis siswa tersebut, yaitu model pembelajaran Ingkuiri terbimbing.

Berdasarkan hasil analisis deskriptif dari data yang diperoleh melalui tes kemampuan koneksi matematis siswa, pada posttest kelas eksperimen diperoleh nilai rata-rata yang lebih tinggi dari pada nilai rata-rata yang diperoleh pada posttest kelas kontrol. Berdasarkan nilai rata-rata, maka kemampuan koneksi matematis siswa kelas eksperimen lebih tinggi dari kemampuan koneksi matematis siswa kelas kontrol. Hal ini mengindikasikan bahwa dari indikator rata-rata, model pembelajaran ingkuiri terbimbing mampu memberikan pengaruh yang cukup baik dalam meningkatkan kemampuan koneksi matematis siswa. Dari indikator keragaman data (varians), data posttest kelas eksperimen memiliki varians lebih kecil dibandingkan varians data posttest kelas kontrol. Nilai varians dari kedua data tersebut menunjukkan bahwa kemampuan koneksi matematis siswa kelas kontrol lebih beragam daripada kelas 
eksperimen. Dari indikator Skewness (kemiringan), kelas eksperimen memiliki lebih banyak siswa yang kemampuan koneksi matematis siswa di atas rata-rata, sedangkan pada kelas kontrol memiliki lebih banyak siswa yang kemampuan pemecahan masalah di bawah rata-rata. Median (nilai tengah) dan nilai yang sering muncul (modus) dari hasil posttest kelas eksperimen lebih tinggi dibandingkan dengan hasil pada posttest kelas kontrol.

Deskripsi kemampuan koneksi matematis siswa pada kelas eksperimen dan kelas kontrol terlihat jelas kemampuan koneksi matematis siswa kelas eksperimen lebih baik jika dibandingkan dengan kelas kontrol, baik dilihat dari nilai maksimum, minimum, rata-rata, median, modus, standar deviasi, varians, serta skewnessnya.

Pengujian hipotesis dalam penelitian ini menggunakan uji-t. Berdasarkan hasil uji hipotesis dengan menggunakan uji-t diperoleh sig. 2-tailed $=0,000<\alpha=0,05$, sehingga $\mathrm{H}_{0}$ ditolak. Dengan ditolaknya $H_{o}$ maka dapat disimpulkan terdapat pengaruh positif yang signifikan pengaruh penerapan model pembelajaran ingkuiri terbimbing terhadap kemampuan koneksi matematis siswa. Dengan kata lain, secara signifikan model pembelajaran ingkuiri terbimbing lebih efektif dibandingkan dengan pembelajaran konvensional untuk meningkatkan kemampuan koneksi matematis siswa. Hal ini diiperkuat oleh penelitian yang dilakukan oleh Novrian (2016) kemampuan komunikasi matematis siswa yang mengikuti pembelajaran dengan model pembelajaran Ingkuiri Terbimbing lebih tinggi daripada siswa yang mengikuti pembelajaran konvensional ditinjau dari keefektifan penerapan pembelajaran. Hal ini terjadi karena dalam proses pembelajarannya, model pembelajaran Ingkuiri terbimbing lebih menekankan peran aktif siswa untuk menemukan berbagai cara penyeesaian masalah matematika yang diberikan.

Hasil yang lebih baik dari siswa yang diajar dengan model pembelajaran ingkuiri terbimbing tersebut disebabkan oleh pelaksanaan model pembelajaran inkuiri terbimbing memberikan kesempatan seluasluasnya kepada siswa untuk memproduksi banyak gagasan (ide), mengajukan bermacam-macam pendekatan atau bermacam-macam jalan (alternatif) pemecahan masalah yang lain. Di sini kemampuan memilih dan menerapkan strategi dalam menyelesaikan suatu model atau masalah matematika dapat berkembang. Pembelajaran ini juga memudahkan siswa memahami konsep-konsep yang diberikan sebagai pengetahuan baru untuk mereka. Dengan cara ini, siswa dapat mengembangkan kemampuan memahami suuatu model atau masalah matematika. Selain itu, siswa juga dapat memperkaya suatu gagasan atau produk dan kemampuan untuk memerinci detail-detail dari suatu objek, ide, dan situasi sehingga mengembangkan kemampuan siswa dalam menjelaskan dan mengiterpretasikan hasil sesuai dengan permasalahan yang diberikan. Ketika siswa dihadapkan pada suatu masalah, siswa diberikan kesempatan untuk terlibat aktif dalam proses memecahkan suatu masalah secara kreatif dan menyenangkan, yang mana dapat dilakukan dengan pembelajaran yang berkelompok. Sehingga dengan belajar berkelompok, masalah yang berat menjadi lebih mudah dipahami dan dipecahkan karena masalah tersebut menjadi tanggung jawab bersama dalam tiap-tiap kelompok. Berkaitan dengan hal tersebut, maka dapat dikatakan bahwa model pembelajaran inkuiri terbimbing memiliki potensi untuk meningkatkan kemampuan koneksi matematis siswa. Hal ini tentunya akan berdampak pada peningkatan mutu hasil belajar matematika siswa yang sangat diharapkan dalam pendidikan. 


\section{Simpulan dan Saran}

\section{Simpulan}

Berdasarkan hasil penelitian dan pembahasan, maka peneliti mengemukakan kesimpulan sebagai berikut.

1. Deskripsi kemampuan koneksi matematis siswa kelas VIII 1 SMP Negeri 10 Kendari yang diajar dengan menggunakan model pembelajaran ingkuiri terbimbing pada pokok bahasan relasi dan fungsi diperoleh nilai rata-rata 78,35; standar deviasi 5,07; varians 25,73; median 80,00; modus 80,00; nilai minimum 72,00 dan nilai maksimum 92,00 serta skewness 0,526.

2. Deskripsi kemampuan koneksi matematis siswa kelas VIII $_{6}$ SMP Negeri 10 Kendari yang diajar dengan menggunakan model pembelajaran konvensional pada pokok bahasan relasi dan fungsi diperoleh nilai rata-rata 72,14; standar deviasi 5,40; varians 29,12; median 82,00; modus 72,00; nilai minimum 60,00 dan nilai maksimum 80,00 serta skewness 0,214 .

3. Terdapat pengaruh positif yang signifikan penggunaan model pembelajaran inkuiri terbimbing terhadap kemampuan koneksi matematis siswa di kelas VIII SMP Negeri 10 Kendari.

\section{Saran}

Berdasarkan hasil penelitian ini, maka peneliti mengemukakan saran-saran sebagai berikut.

1. Seorang guru harus dapat memperhatikan keadaan siswa dalam menerapkan model pembelajaran ingkuiri terbimbing, karena tidak setiap siswa dapat dengan mudah menyesuaikan diri mengembangkan kemampuan koneksi matematis yang dimiliki. Selain itu pembagian kelompok oleh guru harus dilakukan secara heterogen agar dapat terjalin kerjasama yang baik dalam suatu kelompok.

2. Bagi peneliti selanjutnya yang hendak mengembangkan penelitian ini dapat melakukannya pada pokok bahasan lain dengan memperhatikan alokasi waktu pembelajaran sehingga proses pembelajaran dengan model pembelajaran ingkuiri terbimbing bisa berjalan lebih optimal.

\section{Daftar Pustaka}

Arikunto. (2012). Dasar-Dasar Evaluasi Pendidikan. Jakarta: Bumi Aksara.

Jihad, Asep dan Haris, Abdul. (2008). Evaluasi Pembelajaran. Yogyakarta: Multi Presindo.

Maguire, L dan M. Lindsay. (2010). Eksploring Osmosis and Diffusion in Cels. Diakses dari http://ctge_5634.

Wikispaces.com/file/view/Diffusi on.Osmosis.pdf.November 2016.

NCTM.(1989). Curriculum and Evaluation Standards for School Mathematics. Reston, VA: NCTM.

Paidi. (2007). Peningkatan Scientific Skill Siswa Melalui Implementasi Metode Guided Ingkuiry pada Pembelajaran Biologi di SMAN 1 Sleman. Diakses dari http://staf.uny.ac.id/20Paidi.UNY. pdf. November 2015.

Ruseffendi.(1979). Pengajaran Matematika Modern untuk Orang Tua Murid dan SPG. Bandung: Tarsity.

Sanjaya, Wina. (2009). Strategi Pembelajaran yang Berorientasi Standar Proses Pendidiikan. Jakarta: Kencana Prenada Media Group. 
Sugiyono. (2007). Statistik Untuk Widarti,A.(2013). Kemampuan Koneksi Penelitian. Bandung:Alfabeta

Sundayana, R. (2016). Statistika Penelitian Pendidikan. Bandung: Alfabeta.

Suyitno, Amin. (2004). Dasar Dasar dan Proses Pembelajaran Matematika I. Semarang: FMIPA UNNES. Matematisdalam Menyelesaikan Masalah Kontekstual Ditinjaudari Kemampua Matematis Siswa.Skripsi. Jombang: STKIP PGRI Jombang. 